\title{
Determination of the spreading-velocity of nitroaromatic compounds in aquifers represented on the basis of column tests under in situ conditions
}

\author{
F. Jaenig \\ Mull \& Partner Consulting Engineers, Hanover, Germany
}

\begin{abstract}
Groundwater in the discharge area of former ammunition production facilities often reveals severe contamination by production residues and waste products. Thus, these can cause a health hazard to human beings in the case untreated water is consumed. Based on a case study dealing with a more than $1.5 \mathrm{~km}$ elongated contamination plume consisting of various nitroaromatic compounds (NACs) such as TNT, DNT, DNB, TNB, ADNT and DNN the transportation mechanisms were investigated for implementing a reliable risk-assessment. Column tests were carried out by using both local soil in undisturbed cores and the contaminated local groundwater. The investigations showed that the sorption and respectively the velocity of transportation of every NAC strongly correlates with the percentage composition of clay and organic matter in the soil as well as with their own concentration in solution, resulting in complex interactions between single NACs. Nevertheless the parameters obtained from the column tests for retardation, adsorption-capacity and the resultant mobility of the NACs are confirmed by the observed spreading of the contamination plume in situ. Although a time-dependent distribution of the NACs in the wells downstream can be observed, no notable degradation of their total concentration could be ascertained up to now. Therefore calculations were made in view of the amount of the former waste products, their amount of NACs, the soil parameters quoted above and the dissolution-capacity of NACs for determining the former infiltration and respectively the expected duration of dissolution and desorption.

Keywords: nitroaromatic compounds, sorption, spreading-velocity, multicompound system.
\end{abstract}




\section{Introduction}

With the example of an anonymous German explosives plant we have to deal with a former production area used for military production during times of war. There, from 1918 until 1922 waste waters from dismantling ammunition were sunk into a deep-reaching extended aquifer of high permeability, causing a widespread contamination plume. The remediation of groundwater, e.g. by pump and treat, is extremely cost-intensive because of the aquifer's high permeability. This leads us to consider (enhanced) natural attenuation. For this and for calculating "pump and treat" as well a thorough investigation of the nitroaromates' transportation mechanisms is required. Therefore, the spatial future spreading of the contamination plume must be predicted on the basis of an examination of the past spreading, which has taken place in a period of 90 years. A laboratory investigation program established by Jänig [1] showed that the $R_{d}$ of the refined and homogeneous cretaceous quartz sands building up the aquifer, are dependent on the smallest contents of fines and organic matter. Only small variations in these contents lead to significant variation in the retardation behaviour. So the test series were designed for producing parameters for retardation $\left(R_{d}\right)$, partition coefficients $\left(\mathrm{K}_{\mathrm{d}}\right)$ and the resultant adsorption-capacity as well as the resultant mobility of the NACs $\left(\mathrm{v}_{\mathrm{aNAC}}\right)$ in compliance with the qualitative and quantitative influence of various contents of both fines and organic matter in the soil. An application of the results on field dimension showed a good correspondence to the spreading of the contamination plume in situ.

This is followed by inquiries about the amount on the former production residues / waste products and their amounts of NACs sunken in the aquifer. In combination with a calculation basing on the soil parameters for determining the expected lasting of dissolution and desorption, the progress of the contamination plume can be indicated.

\section{Laboratory investigations}

In order to receive $R_{d}$ under defined random conditions, column tests were carried out. For creating nearly pristine conditions local soil samples taken in undisturbed cores and the local groundwater were used. The test-fluid was gained from a well amid the contamination plume. Its chemical composition is given as follows: $25 \mu \mathrm{g} / 1 \mathrm{TNT}, 4.09 \mu \mathrm{g} / 1$ 2,3-DNT, $77.2 \mu \mathrm{g} / 1$ 2,4-DNT, $5.46 \mu \mathrm{g} / 1$ 3,4-DNT, 78.1 $\mu \mathrm{g} / 1$ 1,2-DNB, $160 \mu \mathrm{g} / 1$ 1,3-DNB, $9.12 \mu \mathrm{g} / 1$ 1,4-DNB, $29.8 \mu \mathrm{g} / 1$ 2-A-4,6-DNT, $40.0 \mu \mathrm{g} / 1$ 4-A-2,6-DNT, $4.11 \mu \mathrm{g} / 1$ 1,5-DNN, $42.3 \mu \mathrm{g} / 1$ 1,8-DNN and $5.0 \mu \mathrm{g} / \mathrm{l} \mathrm{TNB}$. This amounts to a total content of $708 \mu \mathrm{g} / \mathrm{l}$ of NACs. The undisturbed core samples were available from 3 locations situated in the back part of the contamination plume taken from different depths of the aquifer. Hence, it was possible to choose a wide spectrum of different grain size distribution and content of organic matter of the soils. The soil-mechanical and mineralogical parameters of the samples are given in table 1 .

The column tests were carried out with a hydraulic gradient of 0.669 , which is exactly 100 times the value of the natural groundwater flow in the aquifer. 
Table 1: Soil-mechanical and mineralogical parameters of the cores investigated.

\begin{tabular}{|c|c|c|c|c|c|c|c|c|c|c|c|}
\hline \multicolumn{3}{|c|}{$\begin{array}{l}\text { Core/ } \\
\text { location }\end{array}$} & \multicolumn{3}{|c|}{ Grain size distribution [\%] } & \multirow{3}{*}{$\begin{array}{c}\begin{array}{c}\text { Organic } \\
\text { matter }\end{array} \\
{[\%]}\end{array}$} & \multirow{2}{*}{\multicolumn{5}{|c|}{$\frac{\text { Mineralogy }}{\text { in fraction }<2 \mu \mathrm{m}^{1)}}$}} \\
\hline & & \multirow{2}{*}{ 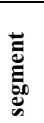 } & Clay & Silt & Sand & & & & & & \\
\hline & $\mathbf{m}$ & & $<2 \mu \mathrm{m}$ & $<63 \mu \mathrm{m}$ & $<2 \mathrm{~mm}$ & & Qz & $\mathbf{K a}$ & Il & $\mathbf{S}$ & G \\
\hline \multirow{8}{*}{$\begin{array}{l}\text { VV } \\
\text { A }\end{array}$} & \multirow[t]{7}{*}{8} & 10 & \multirow{6}{*}{12.91} & 0.69 & 99.31 & 0.09 & \multirow{6}{*}{+} & \multirow{6}{*}{ +H } & \multirow{6}{*}{+} & & \\
\hline & & 20 & & 0.40 & $\begin{array}{l}99.63 \\
\end{array}$ & 0.09 & & & & & \\
\hline & & 30 & & 0.42 & 99.58 & 0.09 & & & & & \\
\hline & & 40 & & 0.78 & 99.22 & 0.09 & & & & & \\
\hline & & 50 & & 0.38 & 99.62 & 0.10 & & & & & \\
\hline & & 60 & & 0.93 & 99.08 & 0.09 & & & & & \\
\hline & & 70 & \multirow{2}{*}{22.80} & 1.20 & 98.80 & 0.17 & \multirow[b]{2}{*}{+} & \multirow[b]{2}{*}{++} & \multirow[b]{2}{*}{++} & & \\
\hline & 7 & 80 & & 1.41 & 98.59 & 0.19 & & & & & \\
\hline \multirow{8}{*}{$\begin{array}{l}\text { TC V } \\
\text { B }\end{array}$} & 16 & 10 & & 0.57 & 99.43 & 0.06 & & & & & \\
\hline & & 20 & & 0.45 & 99.55 & 0.05 & & & & & \\
\hline & & 30 & & 0.55 & 99.45 & 0.06 & & & & & \\
\hline & & 40 & 508 & 0.62 & 99.38 & 0.05 & & & & & \\
\hline & & 50 & 5.90 & 0.43 & 99.57 & 0.05 & + & +++ & ${ }^{++}$ & & \\
\hline & & 60 & & 0.40 & 99.60 & 0.05 & & & & & \\
\hline & & 70 & & 0.49 & 99.52 & 0.05 & & & & & \\
\hline & 15 & 80 & & 0.42 & 99.58 & 0.04 & & & & & \\
\hline TC 1 & 7 & 10 & & 0.89 & 99.11 & 0.12 & & & & & \\
\hline $\mathbf{A}$ & & 20 & & 0.84 & 99.16 & 0.12 & & & & & \\
\hline & & 30 & & 0.78 & 99.22 & 0.11 & & & & & \\
\hline & & 40 & & 0.61 & 99.39 & 0.11 & & & & & \\
\hline & & 50 & 7.20 & 0.67 & 99.33 & 0.10 & + & ++ & +++ & & \\
\hline & & 60 & & 0.68 & 99.32 & 0.13 & & & & & \\
\hline & & 70 & & 0.71 & 99.29 & 0.11 & & & & & \\
\hline & 6 & 80 & & 0.73 & 99.27 & 0.10 & & & & & \\
\hline TC 2 & 6 & 10 & & 1.68 & 98.32 & 0.21 & & & & & \\
\hline $\mathbf{A}$ & & 20 & $11 . / 0$ & 1.98 & 98.02 & 0.22 & ++ & +H+ & + & & \\
\hline & & 30 & 10.56 & 1.74 & 98.26 & 0.24 & & & & & \\
\hline & & 40 & & 1.80 & 98.20 & 0.29 & & & & & \\
\hline & & 50 & & 1.86 & 98.14 & 0.31 & & & & & \\
\hline & & 60 & 11.70 & 1.77 & 98.23 & 0.27 & H & H+ & + & & \\
\hline & & 70 & & 1.58 & 98.42 & 0.22 & & & & & \\
\hline & 5 & 80 & & 0.98 & 99.02 & 0.22 & & & & & \\
\hline TC 3 & 15 & 10 & 2.77 & 1.30 & 98.70 & 0.10 & ++ & +++ & + & & ++++ \\
\hline $\mathrm{C}$ & & 20 & & 1.20 & 98.80 & 0.13 & & & & & \\
\hline & & 30 & & 1.11 & 98.90 & 0.11 & & & & & \\
\hline & & 40 & & 1.50 & 98.16 & 0.12 & & & & & \\
\hline & & 50 & 6.62 & 1.48 & 98.52 & 0.11 & ++ & +++ & + & & $+H+1$ \\
\hline & & 60 & 2.77 & 1.35 & 98.65 & 0.10 & ++ & +++ & + & & $++4+$ \\
\hline & & 70 & & 1.44 & 98.56 & 0.09 & & & & & \\
\hline & 14 & 80 & & 1.14 & 98.86 & 0.12 & & & & & \\
\hline TC 4 & 2 & 10 & 5.53 & 1.41 & 98.59 & 0.47 & +++ & $+++H$ & +++ & + & \\
\hline $\mathbf{A}$ & & 20 & 1.18 & 1.16 & 98.84 & 0.10 & ++ & +++ & ++ & & \\
\hline & & 30 & 2.01 & 1.61 & 98.39 & 0.17 & ++ & +++ & ++++ & + & \\
\hline & & 40 & 7.14 & 0.76 & 98.87 & 0.28 & + & + & & & \\
\hline & & 50 & 10.26 & 1.08 & 98.92 & 0.47 & + & + & & & \\
\hline & & 60 & 19.80 & 2.58 & 97.42 & 2.19 & ++ & + & & & \\
\hline & & 70 & 11.75 & 6.31 & 93.69 & 1.47 & ++ & +++ & & + & \\
\hline & 1 & 80 & 1967 & 458 & 9429 & 201 & 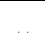 & +1 & & + & \\
\hline & 1 & $80 \mathrm{a}$ & 19.07 & 7.00 & 34.29 & 2.01 & ++ & +H & & + & \\
\hline & & & & & & & & & & & \\
\hline
\end{tabular}


Breakthrough curves (BTCs) were recorded in order to find out the timedependent behaviour of the spreading. Therefore, water samples were not only taken in a single distance from the injection level but also in 3 different levels in between. For determining $\mathrm{R}_{\mathrm{d}}$ and sorption of the NACs depending on soil type and flow distance, BTCs of the almost ideal tracer $\mathrm{Cl}^{-}$were compared with the BTCs of every single analyzed NAC at every single level of a column.

\subsection{Sorption and retardation}

Table 2 shows the differing $\mathrm{R}_{\mathrm{d}}$ for each NAC depending on the type of soil in the columns, see additionally table 1 .

Table 2: $\quad$ Factors of retardation in comparison with the composition of the soils. Mean values are determined for a single column.

\begin{tabular}{|l|c|c|c|c|c|c|}
\hline $\mathbf{R}_{\mathbf{d}}$ & $\mathbf{V V}$ & TC V & TC 1 & TC 2 & TC 3 & TC 4 \\
\hline 2,4,6-TNT & 1.47 & 1.47 & 1.56 & 1.85 & 2.00 & 15.55 \\
\hline 2,3-DNT & 1.21 & 1.19 & 1.88 & 2.44 & 1.72 & 15.95 \\
\hline $\mathbf{2 , 4 - D N T}$ & 1.50 & 1.54 & 1.27 & $2.29 / 221.98$ & 1.52 & 15.29 \\
\hline 3,4-DNT & 1.25 & 1.19 & 1.59 & 2.39 & 1.85 & 20.45 \\
\hline $\mathbf{1 , 2 - D N B}$ & 1.27 & 1.21 & 7.68 & 5.24 & $2.32 / 61.91$ & 29.67 \\
\hline $\mathbf{1 , 3 - D N B}$ & 1.43 & 1.30 & 2.06 & 2.41 & 2.21 & 18.38 \\
\hline $\mathbf{1 , 4 - D N B}$ & 1.16 & 1.22 & 1.64 & 2.08 & 1.69 & 14.52 \\
\hline 2-ADNT & 1.33 & 1.15 & 1.79 & 3.44 & 1.53 & $19.79 / 39.87$ \\
\hline 4-ADNT & 1.20 & 1.15 & 1.76 & 2.67 & 1.48 & 19.61 \\
\hline 1,5-DNN & 6.78 & 1.25 & 6.53 & 32.29 & 2.05 & $12.49 / 125.06$ \\
\hline 1,8-DNN & 2.50 & 1.49 & 3.14 & 9.54 & 1.84 & $19.16 / 69,74$ \\
\hline 1,3,5-TNB & 1.35 & 1.50 & 1.51 & 2.02 & 1.88 & 24.29 \\
\hline
\end{tabular}

In order to find out a superior sequence of mobility, main values were determined for each NAC. Thus, the following sequence is formed (increasing $\left.\mathrm{R}_{\mathrm{d}}\right):$ 1,4-DNB $<$ 4-ADNT/TNT $<2,3-\mathrm{DNT}<3,4-\mathrm{DNT} / 1,3-\mathrm{DNB}<\mathrm{TNT} / 4-$ $\mathrm{ADNT}<2-\mathrm{ADNT} / 3,4-\mathrm{DNT}<\mathrm{TNB}<1,3-\mathrm{DNB} / 2-\mathrm{ADNT}<1,2-\mathrm{DNB} / 1,8-\mathrm{DNN}$ $<1,8-\mathrm{DNN} / 1,2-\mathrm{DNB}<1,5-\mathrm{DNN}<2,4-\mathrm{DNT}$. The sequence reveals for some NACs high and low $\mathrm{R}_{\mathrm{d}}$. This is explained by different concentrations of the sorbates in solution depending on the soil composition, at which they are preferentially adsorbed. Thus, the position partners are read as competitive partner substances. It is evident, that competitive adsorption accelerates the fieldvelocity of weakly-bounded NACs.

For some NACs specific adsorption was established: 1,5-DNN and TNT adsorb on clay; 2,4-DNT, 1,2-DNB, 1,8-DNN adsorb on organic matter; 2ADNT and 4-ADNT adsorb on both, clay and organic matter; 2,4-DNT and 1,2DNB adsorb on both, organic matter and goethite. 2,3-DNT, 3,4-DNT, 1,3-DNB, 1,4-DNB and TNB do adsorb unspecifically without any preference on clay, organic matter, hydroxides and quartz as well.

Because the part of specific sorption cannot be differentiated in pristine multicompound systems, the influence on retardation of any adsorbent cannot be determined quantitatively. Merely an increasing of the field-velocity is indicated, when the amount of adsorbents in the soil decreases. Therefore, in the ultra-pure 
quartz sands field-velocities of some ten m/a are obtained for the NACs. In sand enriched with potential adsorbents though, mobility decreases and fieldvelocities of only a few $\mathrm{m} / \mathrm{a}$ can be found, see table 3 .

Table 3: Spreading-velocity of some of the nitroaromatic compounds investigated.

\begin{tabular}{|c|c|c|c|c|c|c|c|c|c|}
\hline \multirow{3}{*}{ NAC } & \multicolumn{3}{|c|}{$\mathbf{R}_{\mathrm{d}}$} & \multicolumn{6}{|c|}{ spreading } \\
\hline & \multirow{2}{*}{$\min ^{1}$} & \multirow{2}{*}{$\max ^{2}$} & \multirow{2}{*}{$\begin{array}{l}\text { mean } \\
\text { value }\end{array}$} & \multicolumn{2}{|c|}{$\min$} & \multicolumn{2}{|c|}{$\max$} & \multicolumn{2}{|c|}{ mean value } \\
\hline & & & & $\mathbf{m} / \mathbf{a}$ & $\mathrm{m} / \mathbf{9 0 a ^ { 3 }}$ & $\mathbf{m} / \mathbf{a}$ & $\mathrm{m} / \mathbf{9 0 a}$ & $\mathbf{m} / \mathbf{a}$ & $\mathrm{m} / \mathbf{9 0 a}$ \\
\hline $2,4,6-T N T$ & 1.47 & 15.55 & 3.98 & 21.45 & 1,931 & 2.03 & 183 & 7.92 & 713 \\
\hline 2,3-DNT & 1.19 & 15.95 & 4.07 & 26.50 & 2,385 & 1.98 & 178 & 7.75 & 698 \\
\hline 2,4-DNT & 1.50 & 221.98 & 103.76 & 21.02 & 1,892 & 0.14 & 13 & 0.30 & 27 \\
\hline 3,4-DNT & 1.19 & 20.45 & 4.79 & 26.50 & 2,385 & 1.54 & 139 & 6.58 & 592 \\
\hline 1,2-DNB & 1.21 & 61.91 & 17.83 & 26.06 & 2,345 & 1.77 & 159 & 1.77 & 159 \\
\hline 1,3-DNB & 1.30 & 18.38 & 4.63 & 24.26 & 2,183 & 1.72 & 155 & 6.81 & 613 \\
\hline 1,4-DNB & 1.16 & 14.52 & 3.72 & 27.19 & 2,447 & 2.17 & 195 & 8.48 & 763 \\
\hline 2-ADNT & 1.15 & 39.87 & 8.19 & 27.42 & 2,468 & 0.79 & 71 & 3.85 & 347 \\
\hline 4-ADNT & 1.15 & 19.61 & 4.65 & 27.42 & 2,468 & 1.61 & 145 & 6.78 & 610 \\
\hline 1,5-DNN & 2.05 & 125.06 & 41.55 & 15.38 & 1,384 & 0.25 & 23 & 0.76 & 68 \\
\hline 1,8-DNN & 1.49 & 69.74 & 14.71 & 21.17 & 1,905 & 0.45 & 41 & 2.14 & 193 \\
\hline $1,3,5-T N B$ & 1.35 & 24.29 & 5.43 & 23.36 & 2,102 & 1.30 & 117 & 5.81 & 523 \\
\hline
\end{tabular}

1) Determined for the pure sands of column $\mathrm{VV}$ and $\mathrm{TC} \mathrm{V}$; for 1,5-DNN at column TC 3.

${ }^{2)}$ Determined for the enriched sands of column TC 4; for 2,4-DNT and 1,2-DNB at column TC 3.

3) Spreading distance after injection during 1918 and 1922.

Table 4: Amount of (ir-)reversibly bounded NACs calculated on the basis of $\mathrm{K}_{\mathrm{d}}$.

\begin{tabular}{|c|c|c|c|c|c|c|c|c|c|c|c|c|}
\hline \multirow{2}{*}{ NAC } & \multicolumn{6}{|c|}{$\mathrm{K}_{\mathrm{d}}[\mathbf{l} / \mathbf{k g}]$} & \multicolumn{6}{|c|}{ Amount of NACs adsorbed in soil $[\mu \mathrm{g} / \mathrm{kg}]$} \\
\hline & $\mathbf{V} \mathbf{V}$ & TCV & TC1 & TC2 & TC3 & TC4 & VV & TCV & TC1 & TC2 & TC3 & TC4 \\
\hline $\begin{array}{l}\text { 2,4,6- } \\
\text { TNT }\end{array}$ & 0.08 & 0.08 & 0.09 & 0.17 & 0.19 & 2.61 & 20.24 & 20.24 & 22.77 & 43.01 & 48.07 & $\begin{array}{c}660 . \\
33\end{array}$ \\
\hline $\begin{array}{l}2,3- \\
\text { DNT }\end{array}$ & 0.04 & 0.03 & 0.14 & 0.29 & 0.13 & 2.63 & 0.16 & 0.12 & 0.57 & 1.19 & 0.53 & $\begin{array}{c}10.7 \\
6\end{array}$ \\
\hline $\begin{array}{c}2,4- \\
\text { DNT }\end{array}$ & 0.09 & 0.09 & 0.04 & 44.91 & 0.09 & 33.54 & 6.95 & 6.95 & 3.09 & $3,467.05$ & 6.95 & $\begin{array}{l}2,58 \\
9.29\end{array}$ \\
\hline $\begin{array}{c}\text { 3,4- } \\
\text { DNT }\end{array}$ & 0.04 & 0.03 & 0.10 & 0.28 & 0.16 & 3.45 & 0.22 & 0.16 & 0.55 & 1.53 & 0.87 & $\begin{array}{c}18.8 \\
4\end{array}$ \\
\hline $\begin{array}{l}1,2- \\
\text { DNB }\end{array}$ & 0.05 & 0.03 & 1.02 & 0.82 & 12.06 & 5.12 & 3.91 & 2.34 & 79.66 & 64.04 & 941.89 & $\begin{array}{c}399 . \\
87\end{array}$ \\
\hline $\begin{array}{c}1,3- \\
\text { DNB }\end{array}$ & 0.08 & 0.07 & 0.16 & 0.28 & 0.22 & 3.10 & 12.80 & 11.20 & 25.60 & 44.80 & 35.2 & $\begin{array}{c}496 . \\
00\end{array}$ \\
\hline $\begin{array}{c}1,4- \\
\text { DNB }\end{array}$ & 0.03 & 0.04 & 0.10 & 0.22 & 0.12 & 2.35 & 0.27 & 0.36 & 0.91 & 2.01 & 1.09 & $\begin{array}{c}21.4 \\
3\end{array}$ \\
\hline $\begin{array}{c}2- \\
\text { ADNT }\end{array}$ & 0.06 & 0.03 & 0.13 & 0.49 & 0.09 & 6.91 & 1.79 & 0.89 & 3.87 & 14.60 & 2.68 & $\begin{array}{c}205 . \\
92\end{array}$ \\
\hline $\begin{array}{c}\text { 4- } \\
\text { ADNT }\end{array}$ & 0.03 & 0.03 & 0.12 & 0.33 & 0.09 & 3.34 & 1.20 & 1.20 & 4.80 & 13.20 & 3.60 & $\begin{array}{c}133 . \\
60\end{array}$ \\
\hline $\begin{array}{c}\text { 1,5- } \\
\text { DNN }\end{array}$ & 0.98 & 0.04 & 0.88 & 6.53 & 0.19 & 22.28 & 4.03 & 0.16 & 3.62 & 26.84 & 0.78 & $\begin{array}{c}91.5 \\
7\end{array}$ \\
\hline $\begin{array}{c}1,8- \\
\text { DNN }\end{array}$ & 0.26 & 0.08 & 0.34 & 1.71 & 0.15 & 12.18 & 11.00 & 3.38 & 14.38 & 72.33 & 6.35 & $\begin{array}{c}515 . \\
21\end{array}$ \\
\hline $\begin{array}{l}\text { 1,3,5- } \\
\text { TNB }\end{array}$ & 0.06 & 0.09 & 0.08 & 0.20 & 0.16 & 4.14 & 0.30 & 0.45 & 0.40 & 1.00 & 0.80 & $\begin{array}{c}20.7 \\
0\end{array}$ \\
\hline
\end{tabular}

Due to the increasing amount of potential adsorbents resulting in decreasing field-velocities, the NACs are (ir-)reversibly bound in the soil, which is described by $\mathrm{K}_{\mathrm{d}}$. Basing on the NAC concentration in the aquifer and the 
calculated mean values for $\mathrm{K}_{\mathrm{d}}$ for each NAC in each column sorption-capacities of only a few $\mu \mathrm{g} / \mathrm{kg}$ up to several $1,000 \mu \mathrm{g} / \mathrm{kg}$ could be calculated, see table 4 .

\subsection{Application on field dimension}

The spreading-velocity of each NAC investigated was determined on the basis of the in situ field-velocity of $v_{a}=31.5 \mathrm{~m} / \mathrm{a}$ and the calculated $\mathrm{R}_{\mathrm{d}}$, see table 3 . Due to the different $R_{d}$ the spreading varies in a wide range; but the parameters determined are confirmed by the time-dependent development of spreading along the axis of the contamination plume, shown in table 5.

Table 5: $\quad$ Spreading of some nitroaromatic compounds in the groundwater since they have been sunk between 1918 and 1922.

\begin{tabular}{|c|c|c|c|c|c|c|c|c|c|c|c|c|c|}
\hline NAC & 1999 & 2005 & 1999 & 2002 & 2005 & 1999 & 2004 & 1991 & 1994 & 1999 & 1991 & 1994 & 2004 \\
\hline TNT & 0.03 & bdl & 399 & 680 & 525 & 247 & 18 & 37 & 180 & 300 & 4.6 & \begin{tabular}{|l}
8.0 \\
\end{tabular} & 13 \\
\hline $\begin{array}{l}2,3- \\
\text { DNT }\end{array}$ & bdl & bdl & 1.8 & 6.3 & 4.42 & 0.2 & 1 & - & 0.36 & 0.3 & 0.3 & 0.49 & 4.6 \\
\hline $\begin{array}{l}2,4- \\
\text { DNT }\end{array}$ & bdl ${ }^{1)}$ & bdl & 55 & 110 & 1.2 & 5.4 & bdl & 9.5 & 12 & 9.1 & 6.6 & 21 & 345 \\
\hline $\begin{array}{l}3,4- \\
\text { DNT }\end{array}$ & bdl & bdl & 2.7 & 10 & 5.31 & 0.3 & 1.6 & 0.2 & 0.06 & 0.3 & 0.5 & 1 & 12 \\
\hline $\begin{array}{l}1,2- \\
\text { DNB }\end{array}$ & bdl & bdl & 61 & - & 61.2 & 5.8 & 57 & 1 & 0.38 & 1.7 & 79 & 150 & 827 \\
\hline $\begin{array}{l}1,3- \\
\text { DNB }\end{array}$ & 0.06 & bdl & 77 & 260 & 5.21 & 0.7 & 87 & 1.8 & 3.8 & 3.1 & 33 & 270 & 6,109 \\
\hline $\begin{array}{l}1,4- \\
\text { DNB }\end{array}$ & bdl & bdl & bdl & - & 8.53 & bdl & 0.3 & bdl & bdl & bdl & 0.9 & 3.9 & 67 \\
\hline $\begin{array}{l}2- \\
\text { ADNT }\end{array}$ & 0.1 & bdl & 45 & 84 & 48.3 & 15 & 3.3 & 0.9 & 2.3 & 3.5 & 0.5 & 1.3 & 1.5 \\
\hline $\begin{array}{l}4- \\
\text { ADNT }\end{array}$ & 0.18 & bdl & 55 & 82 & 65.7 & 19 & 5.5 & 1.2 & 3 & 4.4 & - & 1.9 & 1.7 \\
\hline $\begin{array}{l}1,5- \\
\text { DNN }\end{array}$ & bdl & bdl & 6.5 & 7.82 & 5.35 & 1.6 & 0.5 & bdl & bdl & 2.5 & - & 21 & 3.9 \\
\hline $\begin{array}{l}1,8- \\
\text { DNN }\end{array}$ & bdl & bdl & 54 & 7.82 & 61.6 & 1.7 & 12 & - & 4 & 1.6 & - & 13 & 71 \\
\hline TNB & bdl & bdl & 1.5 & - & 7.36 & 2.5 & 1.4 & 1.5 & 120 & 48 & - & 0.28 & 1.5 \\
\hline $\mathrm{s}[\mathrm{m}]$ & \multicolumn{2}{|l|}{80} & \multicolumn{3}{|l|}{400} & \multicolumn{2}{|l|}{700} & \multicolumn{3}{|l|}{970} & \multicolumn{3}{|c|}{1,400} \\
\hline $\mathrm{t}[\mathrm{a}]$ & 2.7 & & 13.5 & & & 23 & & 32.3 & & & 47 & & \\
\hline
\end{tabular}

${ }^{1}$ bdl: below detection limit.

By linking table 3 and 4, for the high-sorptive 2,4-DNT turns out a fieldvelocity of $22 \mathrm{~m} / \mathrm{a}$ by adsorbing up to $2,500 \mu \mathrm{g} 2,4-\mathrm{DNT}$ per $\mathrm{kg}$ soil at the same time, depending on the type of soil. This results in a reduction of the total amount of 2,4-DNT in the aquifer in case of steady concentrations in solution. This means a self-purification of the groundwater after passing areas of soil with high contents of potential adsorbents takes place. 
The real spreading-velocity in situ is overlain though by the changing of sorption and release processes resulting from changes in the solution phase concentration of the sorbates caused e.g. by the discontinuity of the former source. As a result, in every monitoring well the distribution of NACs varies time-dependently.

For the assessment, if a decreasing of NACs is lasting, since it is initiated by the spreading or if it is just temporarily limited because of the momentary concentration-equilibrium, it is necessary to determine the amount of the initial infiltration of NACs.

Therefore extensive inquiries were made concerning the production and the dismantling of ammunition for the explosives plant presented here between 1918 and 1922.

\section{Inquiries and calculations}

Chemical-analytical investigations showed, that during WW I the following NACs were predominantly used: $52 \%$ TNT, $29 \%$ DNT, $13 \%$ picric acid and $4 \%$ DNN. TNT was used in many types of ammunitions as single compound or in mixtures with various other explosives and/or chemicals. DNN was mainly used in France for military explosives, whereas in Germany it was only processed in civil explosives like perchlorate-mines and explosives for mining. Due to this information and the knowledge of the composition of the plume, it is evident that French ammunition was dismantled as well.

In contrast to WW II, where diverse and complete details can be found concerning production and demilitarization (dismantling of ammunition), e.g. rates and types, the documentation for WW I is incomplete. The reviewed documents [2] provided only basic information, see table 6 .

The details available of the demilitarization are fairly suitable for a rough estimation of the amount of infiltrated NACs. Due to a lack of details about the process of demilitarization (methods, types of ammunition) assumptions had to be made on the basis of typical processes at that time [3]. Therefore, instead of an absolute calculation only a rough estimation is presented as follows:

A dismantling of 39,000 shells is known. By assuming a medium calibre of $8,8 \mathrm{~cm}$ the weight of filling is $0.2-0.6 \mathrm{~kg}$ TNT $+\mathrm{Fp} 60 / 40(=60 \% \mathrm{TNT}+40 \%$ ammonium nitrate). The assumption of a medium content of $40 \%$ TNT results in an amount of $6,240 \mathrm{~kg}$ TNT.

It is known that large quantities of waste water were sunk into the aquifer. By assuming an amount of $20 \%$ TNT in the waste water, $1,248 \mathrm{~kg}$ TNT were infiltrated.

On the assumption that the TNT-input in the aquifer exclusively took place in solution, an amount of $9,600 \mathrm{~m}^{3}$ waste water had been infiltrated.

Due to a solubility of TNT of $130 \mathrm{mg} / 1\left(20^{\circ} \mathrm{C}\right)$ it is started out from a predominant particular input. By assuming an amount of $60 \%$ particles and $40 \%$ dissolved TNT it sums up to $749 \mathrm{~kg}$ particles and $499 \mathrm{~kg}$ dissolved TNT. 
Table 6: $\quad$ Basic data for the explosive plant presented.

\begin{tabular}{|c|c|c|c|}
\hline Type of job & $\begin{array}{l}\text { Product/type of } \\
\text { ammunition }\end{array}$ & $\begin{array}{l}\text { Typical substances } \\
\text { [3] }\end{array}$ & Amount \\
\hline $\begin{array}{l}\text { Production, } \\
\text { civil* }\end{array}$ & $\begin{array}{l}\text { explosives } \\
\text { for mining } \\
\text { Nitrocellulose- } \\
\text { powder } \\
\text { Perchlorate- } \\
\text { explosives }\end{array}$ & $\begin{array}{l}85 \% \text { ammonium } \\
\text { nitrate, } 8 \% \text { TNT, } 3 \% \\
\text { DNT, } 4 \% \\
\text { Nitroglycerine } \\
1,5+1,8-\mathrm{DNN} \\
\text { Nitrocellulose } \\
41 \% \text { potassium } \\
\text { perchlorate, } 32 \% \\
\text { DNB, } 15 \% \\
\text { ammonium nitrate, } \\
12 \% \text { DNN }\end{array}$ & $\begin{array}{l}1915 \\
\Sigma=5,000 \mathrm{t} / \mathrm{a} \\
1925 \\
\Sigma=3,000 \mathrm{t} / \mathrm{a}\end{array}$ \\
\hline $\begin{array}{l}\text { Production, } \\
\text { military }\end{array}$ & $\begin{array}{l}\text { powder } \\
\text { shells (picric acid) }\end{array}$ & picric acid & $\begin{array}{l}\text { July } 1920= \\
58,469 \mathrm{~kg} \\
\text { July } 1920= \\
11,748 \mathrm{~kg}\end{array}$ \\
\hline $\begin{array}{l}\text { Filling, } \\
\text { military }\end{array}$ & $\begin{array}{l}\text { projectiles } \\
\text { shells }\end{array}$ & $\begin{array}{l}44 \% \text { DNB, } 40 \% \\
\text { ammonium nitrate, } \\
16 \% \text { DNN } \\
\text { various compositions }\end{array}$ & - \\
\hline Dismantling & $\begin{array}{l}\text { shells (artillery) } \\
\text { grenades }\end{array}$ & $\begin{array}{l}\text { various compositions } \\
\text { various compositions }\end{array}$ & $\begin{array}{l}\text { July 1919-May } \\
1920=39,000 \\
\text { pc. } \\
\text { July 1919-May } \\
1920=114,580 \\
\text { pc. }\end{array}$ \\
\hline
\end{tabular}

* The civil production is only listed for completing the picture. Subsequently it is not examined.

The dissolution-rate for TNT is $=6.71 \times 10^{-6} \mathrm{~cm}^{2} / \mathrm{s}$. Based on the known density of $1.6 \mathrm{~g} / \mathrm{cm}^{3}$ for TNT and an assumed particle diameter of $0,5 \mathrm{~cm}$ (provided spherical shape) it comes to a period of 26,529 until the particularly infiltrated TNT is completely dissolved. This means a dissolution-rate of $28 \mathrm{~g} / \mathrm{a}$.

For estimating the sorption-capacity of the aquifer the following assumptions are made: The contamination plume has an extension of 2,000 $\mathrm{m}$ (length) $\mathrm{x}$ $500 \mathrm{~m}$ (width) $\mathrm{x} 10-100 \mathrm{~m}$ (depth). This results in a volume of the contaminated aquifer of 55,000,000 $\mathrm{m}^{3}$. Due to a density of $2.65 \mathrm{~g} / \mathrm{cm}^{3}$ (quartz-sand) a mass of $145,750,000 \mathrm{t}$ results. Due to a main adsorption of $34 \mu \mathrm{g}$ TNT per $\mathrm{kg}$ soil the soil in the area of the contamination plume could adsorb up to $4,955 \mathrm{~kg}$ TNT.

For estimating the TNT-concentration in the pore space the volume of the contamination plume is related to the volume of the effective pore space. Due to $\mathrm{n}_{\text {eff }}=25 \%$ a pore space of $13,750,000 \mathrm{~m}^{3}$ is resulting. Due to the total amount of infiltrated dissolved TNT (499 kg) the interstitial water concentration comes to 
$36 \mu \mathrm{g} / \mathrm{l}$. In fact in a distance of approx. 2,000 $\mathrm{m}$ an amount of $35 \mu \mathrm{g} / \mathrm{l} \mathrm{TNT}$ was analyzed in the groundwater. The assumed extension of the plume does correspond to a transportation-time and distribution of solution phase concentration after 90 a.

For estimating the TNT-concentration in a close range to the former seepage pond a smaller volume of the contamination plume has to be calculated. Due to an estimated plume with a length of $200 \mathrm{~m}$ (this means a period of 5 years after infiltration) it amounts to a volume of $1,000,000 \mathrm{~m}^{3}$, resulting in a concentration of $1,996 \mu \mathrm{g} / \mathrm{l}$. In fact, in a distance of approx. $200 \mathrm{~m}$ from the source an amount of $1,020 \mu \mathrm{g} / \mathrm{l}$ was analyzed in the groundwater.

\section{Conclusions}

The calculations show that we have to deal with rather large quantities of infiltrated waste water and amounts of TNT respectively as assumed for the moment.

Due to the amount of $499 \mathrm{~kg}$ of dissolved TNT just the calculations are confirmed for the solution phase concentration: The calculated concentration within the plume after $90 \mathrm{a}$ is verified. The high amounts within the local range represent on the one side the state of the "young" plume approx. 5 a after infiltration. On the other side they represent as well the recent plume in view of the fact of particular infiltration. Through the solubility of the particles, which are more or less immobile because of colmation, the emission of TNT takes place for a long period of time. This is proved by the analyzed concentrations in situ.

It has to be pointed out that the dissolution rate is highly affected by the particle-surface and the in situ conditions, e.g. temperature, rain. Therefore the observed changes of the distribution of NACs in the monitoring wells might be merely temporarily because of short-term changes of the equilibrium concentration.

Due to the estimation that the adsorption-capacity is completely exhausted within the area of the plume, the initial amount of infiltrated dissolved TNT had to be at least $5,500 \mathrm{~kg} ; 10$ times more as assumed. This means as well a $10 \mathrm{fold}$ particular infiltration of TNT. Thus the assumption of a lasting emission is right.

Additionally to an increased infiltration rate it must be taken into account that the total adsorption-capacity is only valid for homogeneous, isotrop aquifers, in which all parts are passed by the NACs. This assumption is not valid in situ: There, the contamination plume is "fingering" through the aquifer and areas are existent, which are not passed by the contamination plume. Therefore the total amount of potential adsorbents cannot be used for adsorption. Thus, the initial amount of infiltrated TNT might be less as $5,500 \mathrm{~kg}$ as well.

One of the main factors affecting pump and treat is "fingering": In order to ensure a continuous extraction of contaminated groundwater, reclamation wells have to be constructed just amid the main contamination stream, which is directly connected with the source.

At the moment the feasibility might be difficult due to less knowledge about the precise composition of the aquifer. 
Additionally pump and treat probably won't be carried out economically because of the continuous emission on the part of the TNT-particles.

\section{Further investigations}

The results quoted above for the basic parameters show that the elaborate test series presented are a fundamental and indispensable basis for a prediction of the future spreading-velocity of the plume. These parameters present the basis for transport modelling, which is taking place currently.

Further inquiries concerning types of ammunition, methods of demilitarisation etc. are necessary for an enhanced assessment of the total discharge.

Concerning "fingering" detailed investigations of the soil would be useful.

\section{References}

[1] Jänig, F., Zum Transportverhalten nitroaromatischer Verbindungen in natürlichen Mehrstoff-Systemen am Beispiel eines ehemaligen Rüstungsstandortes, Diss., Math.-Naturw. Fak. Christian-Albrechts-Univ. Kiel, 2005.

[2] Various documents of the "Reichstreuhandgesellschaft" of the year 1920.

[3] Thieme, J., Umweltrelevante und technische Aspekte der Zerlegung von Munition und Waffen nach dem 1. Weltkrieg/Environmental and technical aspects of dismantling of munitions and weapons after World War I, UBAFB Texte 3/99, Umweltbundesamt Berlin, 1998. 